\title{
2 次形式評価関数の重み行列の一決定法 ${ }^{\dagger}$
}

\author{
武 田常 広*・北森 俊 行**
An Algorithm for Determining the Weighting Matrices of the Quadratic Performance Function

\author{
Tsunehiro TAKedA* and Toshiyuki Kitamori**
}

\begin{abstract}
Linear optimal control theory has been recognized as a powerful tool for control system synthesis. "Optimal feedback control law" is easily obtained by solving matrix Riccati equation, but there is no way other than the trial and error method to determine proper weighting matrices in the quadratic performance function. Hence, the practical use of the theory has been restricted.

This paper proposes an algorithm of systematical determination of the weighting matrices. The algorithm concerns with the previously proposed optimal tracking systems $\left(S_{c}^{*}\right)^{7}$, and is derived by imposing the following requirements on $S_{c}{ }^{*}$, using the asymptotic pole configuration and the conditional stability characteristics of $S_{c} *$ designed with very small weights on inputs ${ }^{8), 9)}$.
\end{abstract}

(1) $S_{c}{ }^{*}$ should remain stable even if open loop gains of plants change from zero to infinity simultaneously.

(2) $S_{c} *$ should have the fastest step response under the condition of (1).

(3) $S_{c} *$ should be decoupled as much as possible under the condition of (1) and (2).

Some examples demonstrate the efficiency of the algorithm. The algorithm can also be used for ordinaly linear optimal regulator and optimal observer syntheses with minor change.

\section{1. はじめに}

線形最適レギュレータ理論では，Riccati 方程式を 解くだけで “最適制御則”が得られる。しかし， 2 次

$\dagger$ 第 16 回計測自動制御学会学術講演会で発表（昭 $52 \cdot 8$ )

* 製品科学研究所 茨城県筑波郡谷田部町東 1-1-4

** 東京大学工学部 東京都文京区本郷 7-3-1

* Industrial Products Research Institute, Tsukuba-gun, Ibaraki

** Faculty of Engineering, University of Tokyo, Bunkyo-ku, Tokyo

(Received October 6, 1980)

(Revised March 20, 1981)
形式評価関数の重み行列をどのように選べばどのよう な制御系が得られるかが不明なため, 重み行列は試行 錯誤によって選ばざるをえず，実用上の大きな障害と なっている. 従来この問題は多くの研究者の研究対象 となってきたが，いまだ十分に解決されていない，特 に, Schultz らは121 1 入出力系に括いてての問題を詳 しく調へ，重み行列の選択による設計を放棄する立場 を取っている，他方，希望の極を実現するための重み 行列の決定法を論じた研究は22 4)，希望の極が先験的 に決まるという仮定に疑問があるし，重み行列は極配 置から一意的には決定しない点4であ問題がある。ま た最近 Stein ら ${ }^{5), 6)}$ は，著者らと同じく極の漸近的性 質を考慮しつつ，極だけでなく固有べクトルも同時に 指定することによって，重み行列を決定する方法を提 案したが，固有べクトルの指定法が明らかでないこ と, 出力行列を変化させて設計しているととに疑問が ある. 本論文はこの重み行列の系統的かつ実用的な決 定法を提案する.

著者らは, 先にパラメータ変動や定值外乱などがあ ってむ定常偏差なく目標入力に追従できる，線形多入 出力最適追従制御系 (以下 $S_{c}$ * と表記する) の設計法を 報告した7). そこでは，制御対象にステップ入力が入 ったときの平衡点を基準とした入出力の変数を $\boldsymbol{u}_{e}(t)$, $\boldsymbol{y}_{e}(t)$ と表わし，つぎの評価関数を最小化して設計し た.

$$
J=\int_{0}^{\infty}\left[\boldsymbol{y}_{e}{ }^{T}(t) Q \boldsymbol{y}_{e}(t)+\dot{\boldsymbol{u}}_{e}^{T}(t)(\rho N) \dot{\boldsymbol{u}}_{e}(t)\right] d t
$$$$
Q, N: m \times m \text { 正定対称, } \rho: \text { 正実スカラー }
$$

そして,$\rho \rightarrow 0$ としたときの $S_{c}$ *の極配置の性質を文 献 8$)$ に, $\rho \rightarrow 0$ として設計したとき, ゲイン減少に関 しほとんど全ての $S_{c}$ *は不安定になる，という条件付 安定性を明らかにし，(i ) $S_{c} *$ に一定の安定度を保証 する．上いう要請を課すととにより $\rho$ を決定する方法 を文献9)に報告した，本論文では残された $Q ， N の$ 決定法を提案する，本設計法は上記の性質を利用する と共に， $S_{c}$ * の応答を速めるためにさらに(ii) 極の総 
和の絶対值を最小にする，（iii) $S_{c}$ *をできるだけ非干 渉化する，という要請を課すことによって得られる。 本設計法は実用性を重視しているので， 3 例によって 具体的に設計される制御系の性質について考察した。 なお，本設計法は $S_{c} *$ につての設計法であるが，入 出力の数が等しい, 最適レギュレータ, 最適オブザー バの設計にあ適用可能である10),11).

\section{2. $S_{c}^{*}$ の設計法と極の漸近的性質}

まず，最適追従制御系 $S_{c}{ }^{*}$ の設計法"7を要約し， $S_{c}{ }^{*}$ の極配置の性質 ${ }^{8)}, S_{c}{ }^{*}$ の条件付安定性 ${ }^{9}$ を説明する.

制御対象は可制御・可観測で右半平面に零点をむた ず，非干渉化可能な，次式で表わされるむのとする.

$$
S_{0}\left\{\begin{array}{l}
\dot{\boldsymbol{x}}(t)=A \boldsymbol{x}(t)+B \boldsymbol{u}(t) \\
\boldsymbol{y}(t)=C \boldsymbol{x}(t)
\end{array}\right.
$$

ここで, $\boldsymbol{x}(t), \boldsymbol{u}(t), \boldsymbol{y}(t)$ はそれぞれ, $n, m, m$ 次の ベクトルであり， $A, B ， C$ は対応する次元をむつ. まず入力成分ごとに一つの積分器をカスケード結合 し, $\boldsymbol{v}(t)=\dot{\boldsymbol{u}}(t)$ を新たに操作量としたつぎの拡大系 $\left(\bar{S}_{0}\right)$ を仮想的な制御対象と考える.

$$
\bar{S}_{0}\left\{\begin{array}{l}
{\left[\begin{array}{l}
\dot{\boldsymbol{x}}(t) \\
\dot{\boldsymbol{u}}(t)
\end{array}\right]=\left[\begin{array}{cc}
A & B \\
0 & 0
\end{array}\right]\left[\begin{array}{l}
\boldsymbol{x}(t) \\
\boldsymbol{u}(t)
\end{array}\right]+\left[\begin{array}{c}
0 \\
I_{m}
\end{array}\right] \boldsymbol{v}(t)} \\
\boldsymbol{y}(t)=\left[\begin{array}{ll}
C & 0
\end{array}\right]\left[\boldsymbol{x}^{T}(t) \boldsymbol{u}^{T}(t)\right]^{T}
\end{array}\right.
$$

ステップ入力が入った場合の平衡点から計った入出力 の変数を $\boldsymbol{v}_{e}(t), \boldsymbol{y}_{e}(t)$ とする.

$$
J=\int_{0}^{\infty}\left[\boldsymbol{y}_{e}^{T}(t) Q \boldsymbol{y}_{e}(t)+\rho \boldsymbol{v}_{e}{ }^{T}(t) N \boldsymbol{v}_{e}(t)\right] d t
$$

(3) 式の評価関数を最小化して得られる拡大最適レギ ユレータ系 $\left(\bar{S}_{c}\right)$ に対し, その伝達関数行列を不変に 保つ変換を施すことによって $S_{c}$ *は設計される。

ここで,つぎの変数を定義する.

$$
\begin{aligned}
& N^{-1}=\Sigma \Sigma^{T}, \quad|\Sigma| \neq 0 \\
& Q=\Gamma^{T} \Gamma, \quad|\Gamma| \neq 0 \\
& T(s)=\Gamma \bar{H}_{0}(s) \Sigma \bar{\phi}_{0}(s)
\end{aligned}
$$

ただし， $\bar{H}_{0}(s)$ は $\bar{S}_{0}$ の伝達関数行列， $\bar{\phi}_{0}(s)$ はその特 性多項式である. また， $S_{c} *$ の特性多項式を $\phi_{c} *(s)$ と 表わす．すると， Riccati 方程式を変形するととによ り,

$$
\begin{aligned}
\phi_{c} *(-s) \phi_{c} *(s)= & \rho^{-m} \bar{\phi}_{0}(-s) \bar{\phi}_{0}(s) \mid \rho I_{m} \\
& +T^{T}(-s) T(s) /\left\{\bar{\phi}_{0}(-s) \bar{\phi}_{0}(s)\right\} \mid \\
= & \rho^{-m} \bar{\phi}_{0}(-s) \bar{\phi}_{0}(s)\left[\rho^{m}\right. \\
& +\rho^{m-1} h_{1}\left(s^{2}\right) /\left\{\bar{\phi}_{0}(-s) \bar{\phi}_{0}(s)\right\} \\
& \left.+\cdots+h_{m}\left(s^{2}\right) /\left\{\bar{\phi}_{0}(-s) \bar{\phi}_{0}(s)\right\}^{m}\right]
\end{aligned}
$$

$$
h_{r}\left(s^{2}\right)=\sum_{i k} \sum_{k} T(-s){ }_{i_{1} \cdots i_{r}}^{k_{1} \cdots k_{r}} T(s) \stackrel{k_{1} \cdots k_{r}}{i_{1} \cdots i_{r}}
$$

$$
\left\{\begin{array}{l}
1 \leq i_{1}<i_{2}<\cdots<i_{r} \leq m \\
1 \leq k_{1}<k_{2}<\cdots<k_{r} \leq m
\end{array}\right.
$$

をうる. $h_{r}\left(s^{2}\right)(r=1,2, \cdots, m)$ は $T(s)$ の $r$ 次小行列式 之, 対応する $T(-s)$ の 次小行列式の積のすべてを 加えたものである.（7)式を利用して，以下の定理が 証明された。

《定理 1》 $\rho \rightarrow 0$ として設計される $S_{c} *$ の絶対值の 有限な極 $\xi_{i}, z$ は拡大系 $\bar{S}_{0}$ の零点 ( $l$ 個) 飞漸近し, 残りの $(\bar{n}-l)$ 個の極 $\xi_{i, B C}$ は， $Q, N$ の值にかかわ らず $m$ 組の $\bar{S}_{0}$ 亿固有な次数 $n_{i}(i=1,2, \cdots, m)$ をむち, $\rho^{-1 / 2{ }^{n}}{ }_{i}$ に比例する半径をむった Butterworth の極配 置（BC) に漸近する，ただし， $B C$ の半径は $Q, N$ の值に依存する.

《定理 2 》一般性を失うことなく, $|Q|=|N|=1$ とすると， $S_{c}{ }^{*}$ の極の相乗積は $\rho^{-m / 2}$ に比例する.

《定理 3 》定常ゲインが減少するとき，(a)制御対 象 $\bar{S}_{0}$ が不安定のとき， $S_{c}$ *はかならず不安定になり， (b) $\bar{S}_{0}$ が安定のとき，十分大きな $\rho$ で設計された $S_{c} *$ は安定であり， $\bar{n}-l>2 m$ を満たす $\bar{S}_{0}$ に対し，十分 小さな $\rho$ で設計された $S_{c}$ *は不安定となる.

(定理終)

定理 1，3 は制御対象を $\bar{S}_{0}$ から $S_{0}$ にかえて考え， $\bar{n} \rightarrow n$ とするととによって，レギュレータ系にもその まま成立する，定理 2 では， $\rho$ が十分小さいとき， (7) 式において $\rho I_{m} \fallingdotseq 0$ としてよいから $\left(\phi_{0}(s)\right.$ は $S_{0} の$ 特性多項式)

$$
\prod_{i=1}^{n}\left|\xi_{i}\right|^{2} \fallingdotseq \rho^{-m} \phi_{0}^{2}(0)\left|T^{T}(0) T(0)\right| \phi_{0}^{2}(0) \mid
$$

となり,やはり, $\rho^{-m / 2}$ にほぼ比例する.よって, 以 下の $Q ， N の$ 決定法はほぼそのまま，最適レギュレー 夕系 $S_{c}$ の設計における， $Q, N$ 決定法 ${ }^{10)}$ ，また，

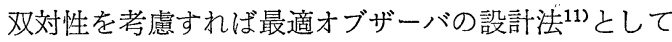
使ってもよいことになる.

つぎそ非干渉制御理論で使われている記法に従い， $C$ の各行を(10)式のように分解し (11) 式の $d_{i}$ を定義 する（非干渉化とは閉ループ伝達関数行列を対角化す るととを意味する $\left.{ }^{14)}\right)$.

$$
\begin{aligned}
C & =\left(\boldsymbol{c}_{1}{ }^{T}, \boldsymbol{c}_{2}{ }^{T}, \cdots, \boldsymbol{c}_{m}{ }^{T}\right)^{T} \\
d_{i} & =\min \left[j \mid \boldsymbol{c}_{i} A^{j} B \neq 0 ; j=0,1, \cdots, n-1\right\}
\end{aligned}
$$

すると, $\bar{H}_{0}(s) \cdot \bar{\phi}_{0}(s)$ の各行の最高次数は $\left(\bar{n}-d_{i}-2\right)$ 次亡なり, その係数は $\boldsymbol{c}_{i} A d_{i} B$ となる. 各行の最高次 の係数 $\left(\boldsymbol{c}_{i} A^{d i} B\right)$ を集めたすのを $H_{1} *$ ，各行の $(\bar{n}-d i$ 一3) 次の係数を集めたものを $H_{2}{ }^{*}$ と表記する． $\bar{S}_{0}$ は 非干渉化可能としたから $\left|H_{1} *\right| \neq 0$ であり，定理 1 の $B C$ の次数は $n_{i}=d_{i}+2$ である. 


\section{3. $\boldsymbol{Q}, N$ の決定法}

\section{3. $1 Q Q, N$ に対する要請}

前章の定理 $1 ， 2$ より，(3)式の評価関数におい $\tau, Q ， N$ 固定し操作量に対する重み $\rho$ を次第に小 さくしていくと， $Q ， N の$ 值にかかわううず，最適追従 制御系 $S_{c}{ }^{*}$ の極は, その絶対值の相乗積が一定で, $\bar{S}_{0}$ に固有な次数をむった $m$ 組の $B C$ に漸近する極 $\xi_{i}, B C$ と， $\bar{S}_{0}$ の零点汇漸近する極 $\xi_{i}, z$ をむつととがわかっ た. この $\xi_{i, z}$ 上零点は極, 零点消去を㧍乙す(注1). しかも，(3)式の評価関数を最小化しているゆえに行 き過ぎ量は大きくない。よって，○が小さい場合， $S_{c}{ }^{*}$ の応答は $n_{i}$ 次の Butterworth Filter がオフセ ットを生じないように， $m$ 組結合した系の応答に近似 できる. 他方, 定理 3 の条件付安定性を考慮した之 き，のはあまり小さくして設計することは許されず, 上記の近似が十分成立する保証はないが，考えやすく するためにつぎの仮定〔A】を置くことにする，仮定の 妥当性については次章で考察する。

〔A〕条件付安定にならない範囲で, できる限り 応答を速くするように設計された $S_{c}{ }^{*}$ の極 は, $\bar{S}_{0}$ の零点と等しい極と, 半径の十分大 きな次数 $n_{i} の m$ 組の $B C$ の極と等しい極吕 ら成り立つ.

このとき， $S_{c}$ * の応答を速めようとして，ある特定の $B C$ の半径を大きくするように $Q, N$ を選ぶと(注2), $S_{c}^{*}$ の極の相乗積が一定のために, 残りの $B C$ の半径 は相対的に小さくなり, 結果的任 $S_{c} *$ の応答は遅いむ のになってしまう，よって， $S_{c}^{*}$ の応答を全体として 速くするために

$$
J_{2}=\left|\sum_{i=1}^{\bar{n}} \xi_{i}\right|, \quad\left(\xi_{i}: S_{c} * \text { の固有值 }\right)
$$

なる $J_{2}$ を最小にするように $Q, N$ を決的るという要 請（ii）を置くことにする.すると， $\left|H_{1} *\right| \neq 0$ の条件 があるので，（7)式より $B C$ の次数と半径は容易に計 算でき, $\min J_{2}$ 之いう条件から一つの条件式が得られ る.

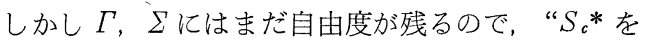
できるだけ非干渉化する”という要請（並）を課して，

（注 1）この極・零点消去はフィードバックによっておきる ので, 可観測性は失われるが可制御性は失われない. よって, 小さなパラメータ変動があっても, 極・零点 消去により隠されていた好ましくないモードが応答に 急に現れるてとはないので, 以下の近似は許される.

(注 2) 定理 1 に示したように(3)式の評伍関数では $Q, N$ によって, $B C$ の次数を変えることができないととが 重要である.文献 6 ) では出力行列 $C$ を制御パラメータ として $B C$ の次数をむ選択している点に問題がある.
$\Gamma ， \Sigma$ の残りの自由度を決めることにする， $S_{c}^{*}$ が非 干渉化されることは，そ机自体好ましいととであるの で，ての要請は受け入れられるととと考える， $S_{c}^{*}$ を 非干渉化することす (7) 式を利用して行える.（7) 式 は, $T(s) / \bar{\phi}_{0}(s)=\Gamma \bar{H}_{0}(s) \Sigma$ という伝達関数行列をむつ 制御対象に対して, $Q=N=I_{m}$ として設計したパワー 特性方程式と同じである. 他方，非干渉化されている 制御対象に対して，対角行列の $Q ， N$ 用いて設計さ れた $S_{c}{ }^{*}$ は非干渉系になる12)。よって， $S_{c}{ }^{*}$ を非干渉 化するためには $\Gamma, \Sigma$ にっって，T(s) を対角行列に すればよいととになる (付録参照)。残念ながら，Г， $\Sigma$ だけでは $T(s)$ を完全に対角化できないが， $S_{c} *$ は 入力にオフセットなく追従することから，定常状態で は，すなわち低周波域では非干啮化されていると解釈 できるよって，T(s)のs认関する最高次から，す なわち高周波域から非干渉化するととが妥当となる。

\section{3. $2 Q, N$ の決定法の導出}

まず， $m$ 組の $B C$ の半径を $r_{i}(i=1,2, \cdots, m)$ と表わ す.さらに $\gamma_{i}, \theta_{i j}$ をつざのように定義する.

$$
\begin{aligned}
& \gamma_{i}=\sum_{j=1}^{n_{i}} \cos \theta_{i j}, \quad(i=1,2, \cdots, m) \\
& \theta_{i j}=\left\{\begin{array}{l} 
\pm \frac{k \pi}{n_{i}}, \quad k=0,1, \cdots, \frac{\left(n_{i}-1\right)}{2} ; \text { if } n_{i} \text { is odd } \\
\pm \frac{(k+1 / 2) \pi}{n_{i}}, k=0,1, \cdots, \frac{n_{i}}{2}-1 ; \text { if } n_{i} \text { is even }
\end{array}\right.
\end{aligned}
$$

$\theta_{i j}$ は負の実軸を基準とした $B C$ の極の偏角， $\gamma_{i}$ はそ の方向余弦の和を表わしている.すると，仮定 $\{A]$ と $B C$ の性質から(15)式をうる.

$$
\left|\sum_{i=1}^{\bar{n}-l} \xi_{i, B C}\right|=\sum_{i=1}^{m} \gamma_{i} r_{i}
$$

他方，仮定〔 $A$ 〕 と定理 2 より

$$
\left|\sum_{i=1}^{n-l} \xi_{i, B C}\right|^{2}=\rho^{-m} \alpha^{2}=\prod_{i=1}^{m} r_{i}{ }^{2 n}{ }_{i}, \quad \alpha \equiv\left|\begin{array}{ll}
A & B \\
C & 0
\end{array}\right|
$$

をうる.よって，(16)式を拘束条件として, Lagrange の方法により(17)式を最小化すると，極の相乗積一定 の条件で, 極の和の絶対値が最小となる $m$ 組の $B C$ の 半径が(18)式の上うに求められる(注3)。(ただし及は Lagrange の乗数である).

$$
L=\sum_{i=1}^{m} \gamma_{i} r_{i}+\beta\left(\prod_{i=1}^{m} r_{i}{ }^{2 n_{i}}-\rho^{-m} \alpha^{2}\right)
$$

（注 $3 ）$ (18)式は $n_{i}$ 次の $B C$ の半径を $n_{i} / r_{i}$ の比で決定する 乙とを意味する.たとえば, $B C$ の次数が 2 次と 3 次の とき, $r_{1}: r_{2}=\sqrt{2}: 1.5$ となり, 次数の大きな $B C$ の 半径ほど大きくなる. 同じ半径の $B C$ をむった系の応 答は次数が大きくなる程整定時間が長くなるので, こ のようにすれば $S_{c}^{*}$ の全体の応答は速まる. 


$$
r_{i}=\frac{2 n_{i}}{\gamma_{i}}\left[\left\{\prod_{i=1}^{m}\left(\frac{2 n_{i}}{\gamma_{i}}\right)^{2 n}{ }_{i}\right\} \rho_{m} \cdot \alpha^{-2}\right]^{-\frac{1}{2(\bar{n}-l)}}
$$

他方, $\bar{H}_{0}(s) \cdot \bar{\phi}_{0}(s)$ の各行の最高次の係数を集めた行 列 $H_{1} *$ を $\Gamma, \Sigma$ にっって,

$$
\begin{aligned}
& \Gamma H_{1} * \Sigma=\Lambda_{1} \\
& \Lambda_{1}=\operatorname{diag}\left(\lambda_{1}, \lambda_{2}, \cdots, \lambda_{m}\right), \quad \lambda_{i} \neq 0
\end{aligned}
$$

のように変形すれば（|$H_{1} * \mid=0$ が成立すれば常に可 能である $\left.{ }^{9)}\right), \xi_{i}, B C$ は $|s| \gg 1$ のき，(19)式を使って (7)式を $s$ の最高次だけで近似した

$$
\begin{gathered}
(-1) \bar{n} \rho-m^{2 \bar{n}} \prod_{i=1}^{m}\left[\rho+(-1)^{\bar{n}-n_{i} S^{2\left(\bar{n}-n_{i}\right)}} \cdot\right. \\
\left.\lambda_{i}{ }^{2} /\left\{(-1)^{\bar{n}} S^{2 \bar{n}}\right\}\right]=0
\end{gathered}
$$

より求まる。(21)式は (22) 式と変形できる。

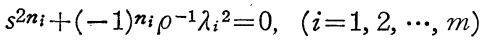

(22) 式の解は半径 $\left(\rho^{-1} \lambda_{i}^{2}\right)^{1 / 2} n_{i}$ の $B C$ の極だから，そ の半径と (18) 式の $r_{i}$ を等しくする条件より次式をう る.

$$
\lambda_{i}=\left[\frac{2 n_{i}}{\gamma_{i}}\right]^{n_{i}}\left[\alpha^{-2} \prod_{i=1}^{m}\left(\frac{2 n_{i}}{\gamma_{i}}\right)^{2 n_{i}}\right]^{-\frac{n_{i}}{2(\bar{n}-l)}} \cdot \rho^{\frac{\bar{n}-l-m n_{i}}{2(\bar{n}-l)}}
$$

すなわち，(23)式を満たす $\lambda_{i}$ によって (20)式のよう に構成される $\Lambda_{1}$ を用いて (19)式を満足させれば，仮 定〔 $A]$ のとで， $B C$ の半径が $r_{i}$ に等しくなり，各 行の最高次について非干渉化される.

つぎに残された自由度によって $T(s)$ の各行の 2 番 目に高次な係数行列 $\mathrm{H}_{2}$ * を対角化する，それには

$\Gamma H_{2} * \Sigma=\Lambda_{2} ; \Lambda_{2}$ : 対存行列

のように $\Gamma ， \Sigma$ を決めればよい。(24)式を変形した

$\Sigma^{-1}=\Lambda_{2}^{-1} \Gamma H_{1} *$

を(19)式へ代入すると

$\Gamma H_{2} * H_{1} * \Gamma^{-1}=\Lambda_{2} \Lambda_{1}^{-1} \equiv \Lambda_{3} ; \Lambda_{3}$ ：対角行列

を得る、ただし， $n_{i}$ が全て等しいとき， $\Gamma$ は $|\Gamma|$ $= \pm 1$ を満たす任意の正則行列でよいが， $n_{i}(i=1,2$, $\cdots, m)$ に等しくないむのがあるとき，異なる次数の係 数間の計算をしてはならないから，「は異なる次数に 対応する行の交換，和を作ってはならないという制限 がつく．たとえば， $n_{i}$ が全て異なるとき， $\Gamma$ は対角 行列でなければならない.しかし， $S_{c} *$ の応答は $\Gamma$ の值によってそれ程大きく変わらないので $\Gamma$ の決め 方は以下の三つの場合にわけて決めれば十分であると 考える.

〔I〕 $n_{1}=n_{2}=\cdots=n_{m}$ のとき, $H_{2} * H_{1} *-1$ が $m$ 個 の実数で独立な固有べクトルをもつとき，その 固有ベクトルによって $|\Gamma|= \pm 1$ となるように
$\Gamma$ を構成する.

〔II〕〔I〕の条件を満たさないが， $H_{2} * H_{1} *-1$ が下 三角行列のとき， $\varepsilon \ll 1$ を使って

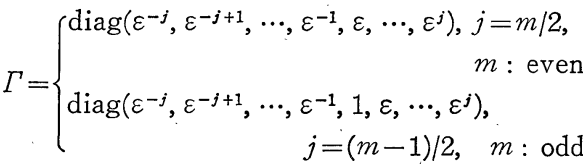

とする．また上三角行列のときは，上式で $j=$ $-m / 2, j=-(m-1) / 2$ とする. とのようにす ると, $\Gamma H_{2}{ }^{*} H_{1}{ }^{*-1} \Gamma^{-1}$ は対角要素が不変であ $り$, 非対角要素は $\varepsilon^{i}$ 倍 $(\varepsilon \ll 1, i:$ 自然数) され る.なお，So が minimal observable で零点 のないとき， $H_{2} * H_{1}{ }^{*-1}$ は三角行列になるとと が証明できる。

〔III〕I〕，〔II〕以外のとき， $\Gamma=I_{m}$ とする. すると〔I〕，〔II〕の場合は $T(s)$ の各行の最高次とつ ぎの次数までほぼ対角化でき，〔亚〕の場合も最高次だ けは対角化できる． $S_{c} *$ は定常状態において非干渉化

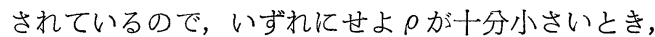
'S $S_{c}^{*}$ はかなりの程度非干涉化されていることが期待で きる。

\section{3. $3 S_{c}^{*}$ の設計アルゴリズム}

上述の議論をアルゴリズムの形にまとめる.

(1) 可制御・可観測で右半平面に零点をむたず, 非干 渉化可能で安定な(1) 式の制御対象 $S$ 。に対し，

(2)式の拡大系 $\bar{S}_{0}$ を仅想的な制御対象と考える.

(2) (11) 式より $n_{i}=d_{i}+2$ を求め, $\bar{H}_{0}(s) \cdot \bar{\phi}_{0}(s)$ の各 行の最高次とつぎの次数の係数行列 $H_{1} *, H_{2}$ * を 求める.

(3) $H_{2} * H_{1} *-1$ をできるだけ対角化する”ように前 節の〔I $\left[\right.$ 〔 III]に従い $\Gamma$ を決める. $Q=\Gamma^{T} \Gamma$ とす る.

(4) $\rho$ の初期值を仮定し，乙れを $\rho_{0}$ とする.

(5) $\lambda_{i}$ を(13), (14), (16), (23) 式により計算し, (20)式の $\Lambda_{1}$ を作る．それを使って，(25)式で $\Sigma^{-1}$ を計算する. $N=\Sigma^{-T} \Sigma^{-1}$ とする。

(6) $Q ， N$ を定として $S_{c}$ *が条件付安定にならない 範囲でできるだけ小さな $\rho$ を探索し，それを $\rho_{m}$ と する ${ }^{9)}$.

(7) $n_{1}=n_{2}=\cdots=n_{m}$ のとき $\lambda_{i}$ は $\rho$ の関数でないの で, (8)へいく. $\left|\left(\rho_{0}-\rho_{m}\right) / \rho_{0}\right|$ が十分小さければ 8 へいく.そうでないとき， $\rho_{0}=\rho_{m}$ として(4)へいく.

(8) 最適フィードバック行列を計算し， $S_{c} *$ を構成す る. 


\section{4. 数值例および考察}

本設計法の有効性を示すために，二つの制御対象に ついて $S_{c}$ *を設計し，その特性を検討する．また，非 干渉制御系との比較考察を行う。

〔例 1〕文献 7)でむ使った 3 次遅れが二つ結合し た 2 入出力系を制御対象 $S_{0}$ とする.

$$
\begin{aligned}
& A=\left(\begin{array}{ccc:ccc}
0 & 1 & 0 & 0 & 0 & 0 \\
0 & 0 & 1 & 0 & 0 & 0 \\
-1 & -3.5 & -3.5 & 0 & 0 & 0 \\
\hdashline 0 & 0 & 0 & 0 & 1 & 0 \\
0 & 0 & 0 & 0 & 0 & 1 \\
-0.1 & -0.2 & -0.4 & -1 & -5.25 & -5.25
\end{array}\right) \\
& B=\left(\begin{array}{cc}
0 & 0 \\
0 & 0 \\
1 & 0.5 \\
0 & 0 \\
0 & 0 \\
0.5 & 1
\end{array}\right) \\
& C=\left[\begin{array}{lll:lll}
1 & 0 & 0 & 0 & 0 & 0 \\
0 & 0 & 0 & 1 & 0 & 0
\end{array}\right]
\end{aligned}
$$

$\left|\bar{H}_{0}(s) \cdot \bar{\phi}_{0}(s)\right|=0.75$ だから零点はない. $S_{0}$ の極は, $(-0.5,-1,-2),(-0.25,-1,-4)$ である. $H_{1} *, H_{2}$ * は

$$
H_{1} *=\left[\begin{array}{ll}
1 & 0.5 \\
0.5 & 1
\end{array}\right], \quad H_{2} *=\left[\begin{array}{ll}
5.25 & 2.625 \\
1.35 & 3.3
\end{array}\right]
$$

で $\left|H_{1}{ }^{*}\right| \neq 0$ であり, $n_{1}=n_{2}=4$ である. よって $\Gamma に$ は制限がなく $|\Gamma|= \pm 1$ を満たす実数正則行列でよ い. $H_{2} * H_{1}{ }^{*-1}$ は下三角行列となるので〔 I 〕の場合に 相当する.よって

$$
\Gamma=\left[\begin{array}{cc}
1 & 0 \\
0.229 & 1
\end{array}\right], Q=\left[\begin{array}{cc}
1.052 & 0.229 \\
0.229 & 1
\end{array}\right]
$$

$\Gamma$ を左式のようにすれば， $Q$ は右式のように求まる. $n_{1}=n_{2}=4$ だから $B C$ 半径 $r_{i}$ は等しく $\Lambda_{1}=\sqrt{0.75}$. $I_{2}$ となり， $\Sigma^{-1}, N$ はつぎのように求まる.

$$
\Sigma^{-1}=\left(\begin{array}{ll}
1.155 & 0.577 \\
0.841 & 1.287
\end{array}\right), \quad N=\left(\begin{array}{ll}
2.04 & 1.750 \\
1.750 & 1.989
\end{array}\right)
$$

上記のように求まった $Q, N$ 用いて $\rho_{m}$ を探索する と, $\rho_{m}=6.87 \times 10^{-5}$ となった.

設計された系を $S_{c} * 1$ と呼ぶ. 比較のために $Q=N$ $=I_{2}$ として同様に設計した系9 ${ }^{9}$ を $S_{c}{ }^{*} 2$ と呼ぶ，設定 值を $\boldsymbol{r}=(0.5,1.0)^{T}$ としたときの $S_{c} * 1, S_{c}{ }^{*} 2$ のテッ プ応答を Fig. 1 に示した（以下の例の設定値は全 て同じあのとする). 図の $y_{i j}$ の添字 $i$ は変数の番号 を示し，添字 $j$ は 1 が $S_{c}^{*} 1$ の応答, 2 が $S_{c} * 2$ の応答 であることを示す． $S_{c} * 1$ の応答は $S_{c} * 2$ のそれに比べ

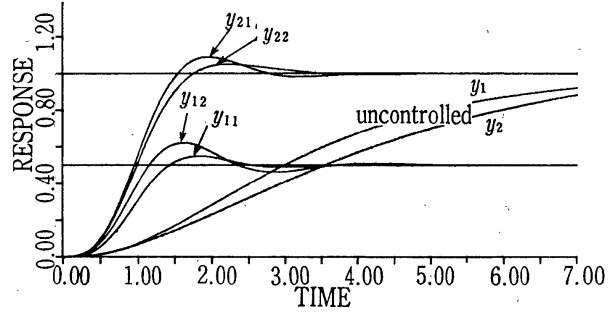

Fig. 1 Step responses of $S_{c} * 1$ and $S_{c} * 2$

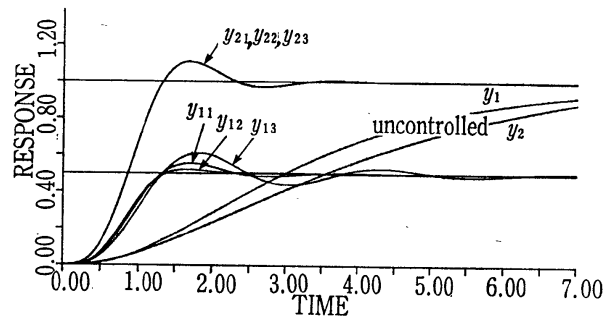

Fig. 2 Step responses of $S_{c} * 1$ when $a_{33}$ is varied; $1: a_{33}=-3.5,2: a_{33}=-1.75,3: a_{33}=-7.0$

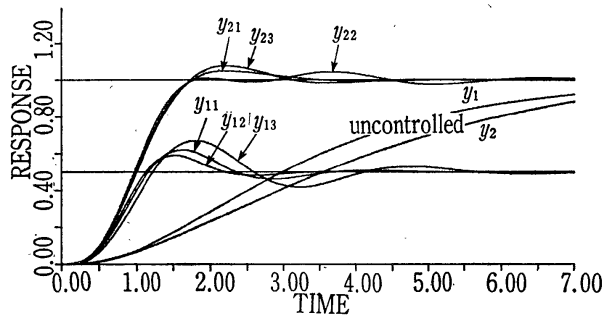

Fig. 3 Step responses of $S_{c} * 2$ when $a_{33}$ is varied; $1: a_{33}=-3.5,2: a_{33}=-1.75, a_{33}=-7.5$

て, $y_{11}$ の行き過ぎ量 が小さくなり， $y_{21}$ は 立ちあがりがよくなっ て，全体として応答の 姿がよくなり，速応性 が改善されているてと がわかる.とこで，行 列 $A$ の要素を $a_{i j}$ 之表 わすととにする． $S_{c}^{*} 1$ に拉いて, 設計後に $a_{33}$ がパラメータ変動 して ${ }^{1 / 2}$ 倍， 2 倍にな ったときの応答をパラ メータ変動がない場合 と比較して Fig. 2 に

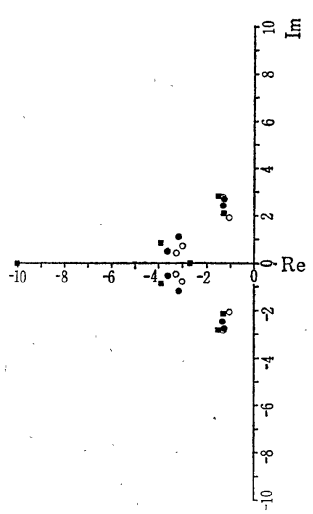

Fig. 4 Pole configurations of optimal tracking systems;

: $S_{c} * 1, \bigcirc: S_{c} 2^{*}$ : $S_{c} * 3$

2,3 の順に, $a_{33}=-3.5,-1.75,-7.0$ 、の場合を 示す. Fig. 3 には, $S_{c} * 2$ について同様に $a_{33}$ がパラ 


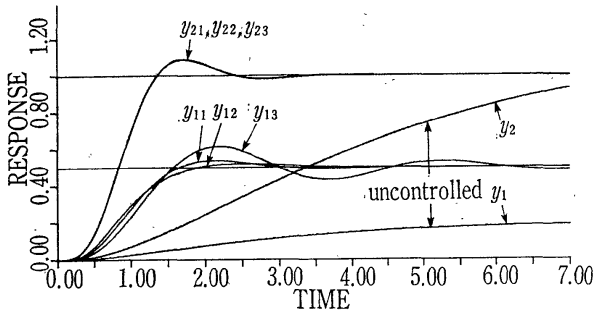

Fig. 5 Step responses of $S_{c}^{*} 4$ when $a_{33}$ is varied; $1: a_{33}=-11.5,2: a_{33}=-5.75,3: a_{33}=-23.0$

メータ変動したときのステップ応答を示した。 $S_{c} * 1$ は確かにほぼ非干渉化されているが， $Q=N=I_{2}$ のよ うに適当に $Q ， N$ を決めて設計された $S_{c} * 2$ は，大き な干渉が残り，パラメータ変動による応答の乱れあ大 きいととがわかる. Fig. 4 亿 $S_{c} * 1 ， S_{c}$ *2 の極を ○で示した. $S_{c} * 1$ はかなりよく 2 組の 4 次の $B C$ に 漸近していることがわかる。したがって，ての場合は 仮定〔A]はかなりの程度満足しているといえる.

〔例 2〕例 1 の系で第 1 のサブシステムの極が（一 $0.5 ，-1 ，-10 ）$ であるすのを制御対象 $S_{0}$ とする. すなわち，行列 $A$ の要素 $a_{i j}$ のうち， $a_{31}, a_{32}, a_{33}$ は 順に $-5,-15.5,-11.5$ であり，Aの残りの要素と $B ， C$ 例 1 のものと等しいとする. 乙の制御対象を 例 1 と同じように設計すると，

$$
\begin{aligned}
& Q=\left[\begin{array}{rr}
1.002 & -0.0390 \\
-0.0390 & 1.0000
\end{array}\right], \\
& N=\left[\begin{array}{ll}
1.617 & 1.269 \\
1.269 & 1.615
\end{array}\right]
\end{aligned}
$$

なり， $\rho_{m}=2.95 \times 10^{-5}$ となった. 設計された系を $S_{c} * 3$ と呼ぶ. Fig. 5 に $S_{c} * 3$ のステップ応答を $a_{33}$ が半分 と倍に変動したときの応答と共に示した。添字 $j$ は 1，2，3 の順に $a_{33}=-11.5,-5.75,-23.0$ である ことを示す. $S_{c} * 1$ に比べて, $y_{1 j}$ の応答が多少遅い が， $a_{33}$ の変動に対して屯大きな影響をうけず，許容 できる応答になっているといえる. Fig. 4 に $S_{c} * 3$ の 極を回で示した． $S_{c} * 6$ の極は， $B C$ の極に十分溸近し ていない. てれは，点 $(-10,0)$ にある極がほとんど 動いていないためである. 一般に $S_{c} *$ の極は， $\rho$ が小 さくなるに従い，原点の近くの屯のから $B C$ の極に漸 近していく傾向をむつ，つまり，応答を速くするため にむだのない極の動かし方をしているといえる．ての 場合仮定〔 $A$ ]は満たされていないのだが，ステップ応 答からは，本設計法はそういった場合にああまり問題 がないといえる.

〔例 3〕本設計法には， $S_{c}$ *を非干渉化することが 目的の一つになっている，そうであれば，直接非干渉 化し，極指定して設計したほうが簡単ですぐれている

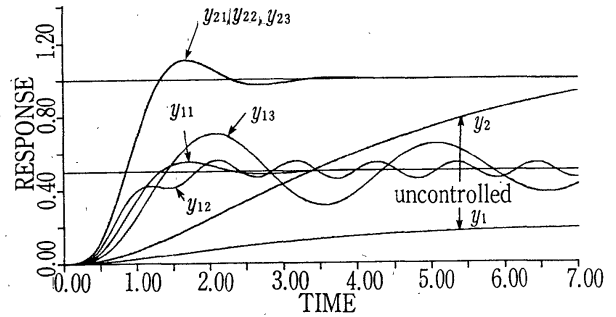

Fig. 6 Step responses of $S_{c}{ }^{\prime}$ (decoupled) when $a_{33}$ is varied;

$1: a_{33}=-11.5,2: a_{33}=-5.75, \quad 3: a_{33}=-23,0$

と考えられるかすしれない.非干渉制御理論では, $\left|H_{1} *\right| \neq 0$ のとき非干渉化されたサブシステムの極を 任意に指定できるアルゴリズムが与えられているが， 極をどのように決定すべきかは述べられていない．そ こで，本設計法と比較が容易なように，非干渉化され たサブシステムの極を(18) 式の半径比をむつ $B C$ の極 に一致させ，条件付安定にならない範囲で $B C$ の半径 を一番大きくするようにフィードバック係数を計算 し， $S_{c}$ *と同じ構造の制御系を構成するととが考えら れる，例 2 の制御対象に対し，乙の設計を行ったら， $B C$ の半径は $r_{1}=r_{2}=3.2$ となった．設計された系を $S_{c}{ }^{\prime} 4$ と表方す. 例 2 と同様に $a_{33}$ を半分と倍に変動さ せたときの応答といっしょにして，Fig. 6 に $S_{c}^{\prime} 4$ の ステップ応答を示した． $S_{c}^{\prime} 4$ の応答は， $S_{c} * 3$ の応答 に比べてパラメータ変動のないときは，y21 の立ちあ がりが速くなっているが，パラメータ変動があるとき は大きく乱れている，S $S_{c}$ * は最適設計しているので感

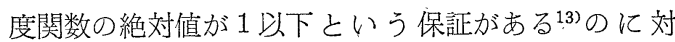
し，本例の設計法にはないとと，極配置から説明すれ ば， $S_{c} * 3$ では減衰の速い $(-10,0)$ の極をほとんど動 かしていないのに対し， $S_{c}^{\prime} 4$ では，それを大きく原点 に近づけていること，に起因していると考えられる. よって，本法は計算量は多少多いが，パラメータ感度 あ一定の保証が与えられた系が，アルゴリズムに従っ て系統的に設計できるという意味で大きな利点をもっ ているといえる.

\section{5. おわりに}

最適追従制御系 $S_{c} *$ の設計における重み行列 $Q, N$ の決定法を提案した。本設計法では, 従来の設計法为 工学的センスを駆使して極配置をまず明確に指定する 必要があるのに対し, $\rho \rightarrow 0$ で実現する Butterworth の極配置 $(B C)$ を暗墨のうちに想定し，（i ) 条件付安 定にならないように一定の安定度を保証する，さらに （ii）極の総和を最小にする，（iii)非干渉化する，とい 
う要請を課すととによって，系統的に重み行列を決め るととが可能となった．本設計法では，仮定〔 $A$ 〕よ うにかなり強引な仮定のもとに論を進めたが, 設計例 で示したように $S_{c}$ *の極配置と $B C$ の極とのずれは絬 果的に問題がない. このととは, 紙面の都合上示せな かったが，このように人工的に作った例だけでなく， 飛行機の設計のような実際的な例についても成立する ことが確かめられている101.

本来, 制御対象の状態方程式は不正確なむのしか得 られないとと, またパラメータ変動や外乱があるのが 普通であるととを考えれば，評価関数の重み行列の決 め方むある程度雑なむのでよいはずだから，本設計法 のように，仮定〔 $A$ 〕に基づいて論を進めたとと， $\Gamma$, $\rho_{m}$ の選び方に任意性が残されたことむ許されるので はないかと考える，その意味では，本設計法によって 設計される $S_{c}^{*}$ は, 真の “最適” 制御系の 1 次近似的 なむのとしなければならない，また，制御対象が(1) 不安定 (2) 右半平面に零点をむつ (3) 非干渉化不可能 な場合に対する設計法は今後の課題として残された。 しかし，典型的な制御対象に関してだけであるが，従 来試行錯誤によってのみ決定された重み行列が，系統 的に決定可能になったとと，また設計される $S_{c}{ }^{*}$ (同 様に $S_{c}$ ) の性質が明確になったてとの意義は大きい あのと考える. 最適制御理論においては, 理論と実際 の乘離が指摘されてきたが，本論文でそのギャップを わずかながらむ埋めたのではないかど考える.

\section{参 考: 文 献}

1) D. G. Schultz and J. L. Melsa: State Function and Linear Control Systems, Chap. 8, 9, McGraw-Hill (1967)

2) J.S. Tyler and F. B. Tuteur: The Use of a Quadratic Performance Index to Design Multivariable Control Systems, IEEE Trans. on Automatic Control, AC-11-1, 84/92 (1966)

3) O. A. Solheim: Design of Optimal Control Systems with Prescribed Eigen Values, Int. J. Control, 151, 143/160 (1972)

4) Y. Shih and C. Chen: On the Weighting Factors of the Quadratic Criterion in Optimal Control, Int. J. Control, 19-5, 947/955 (1974)

5) C. A. Harvey and G. Stein: Quadratic Weights for Asymptotic Regulator Properties, IEEE Trans. on Automatic Control, AC-23-3 (1978).

6) G. Stein: Generalized Quadratic Weights for Asymptotic Regulator Properties, IEEE Trans. on Automatic Control, AC-24-4 (1979)

7) 武田常広, 北森俊行 : 線形多入出力最適追従制御系の一 設計法, 計測自動制御学会論文集, 14-4, 359/364(1978)

8）武田常広, 北森俊行: 線形多入出力最適追従制御系の極 配置の性質，計測自動制御学会論文集， 15-7，858/865 (1979)

9）武田常広, 北森俊行 : 線形多入出力最適追従制御系の条
件付安定性之 $\rho$ の決定法, 計測自動制御学会論文集, $\mathbf{1 6}$ $-1,6 / 13(1980)$

10）武田常広, 北森俊行: 線形多入出力最適追従制御系 $\left(S_{c}{ }^{*}\right)$ の設計法の特徴について, 第19回 SICE 学術講演会予 稿集, 43/44 (1980)

11）武田常広，北森俊行：オブザーバの一設計法；第21回自 動制御連合講演会前刷, 187/188 (1978)

12) P. Hetrakul and T.E. Fortman: Optimal Decoupling of Linear Systems, IEEE Trans. on Automatic Control, AC-17-3 (1972)

13) H. Kwakernaak and R. Sivan: ${ }_{\text {LLinear Optimal }}$ Control Systems, Chap. 2, 3, John-Wiley \& Sons, Inc. (1972)

14) E. G. Gilbert: The Decoupling of Multivariable Systems by State Feedback, SIAM J. on Control, 7 $-1,50 / 63$ (1969)

\section{《付 録》}

$S_{c}$ *を非干渉化するためには， $\Gamma ， \Sigma$ によって $T(s)$ を対角行列すれば十分であるととを一例によって示す (当然ながら， $\rho$ を小さくすればする程よりよく非干 渉化される).

二つの 1 次遅れ系が干渉項をむって結合した $(A .1)$ の系を制御対象とする.

$$
A=\left[\begin{array}{cc}
-a & 0 \\
-b & -c
\end{array}\right], \quad B=C=I_{2}
$$

$$
\text { よって, } \bar{H}_{0}(s) \text { は (A.2) となる. }
$$

$$
\bar{H}_{0}(s)=\left[\begin{array}{cc}
s(s+c) & 0 \\
-b s & s(s+a)
\end{array}\right] / s^{2}(s+a)(s+c)
$$

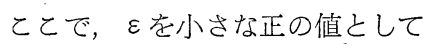

$$
\Gamma=\left(\begin{array}{cc}
1 / \varepsilon & 0 \\
0 & \varepsilon
\end{array}\right), \quad \Sigma=\left(\begin{array}{cc}
\varepsilon & 0 \\
0 & 1 / \varepsilon
\end{array}\right)
$$

と置くと，

$$
T(s)=\left(\begin{array}{cc}
s(s+c) & 0 \\
-\varepsilon^{2} b s & s(s+a)
\end{array}\right)
$$

となり， $\varepsilon \rightarrow 0$ で $T(s)$ は対角化される. 残念ながら, このような簡単な例であ, 多入出力系の場合, Riccati 方程式は手計算で解けないので, $a=b=c=1, \rho=$

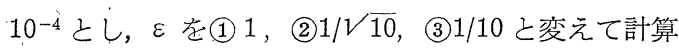
機で解いた．とのときの，拡大最適レギュレータ系 $\bar{S}_{c}$ の極 $\xi_{i}$ とその総和の絶対值々( $\xi_{i}$ は $S_{0}$ * のそれと等 しい), フィードバック係数产を Table 1 に示した. $\varepsilon$ が小さくなるに従い， 2 組の極が 2 次の $B C$ に漸近 し, 極の総和の絶対值が小さくなり, フィードバック 係数の要素 $k_{i j}$ のうち, 下線を引いて示した $k_{12}, k_{14}$ が零に漸近している.

他方，文献14の標準的な非干渉系の設計手法飞従 w,

$$
\boldsymbol{v}(t)=-\bar{K} \overline{\boldsymbol{x}}(t)+G \boldsymbol{r}
$$

の形式で，閉ループ系の伝達関数行列 $\bar{H}_{c}(s)$ を 
Table 1 Poles, absolute values of the sum of the poleo and optimal feedback coefficients; $\rho=10^{-4} ;$ (1) $\varepsilon=1$ (2) $\varepsilon=1 / \sqrt{10}$ (3) $\varepsilon=1 / 10$

\begin{tabular}{|c|c|c|c|c|c|c|c|}
\hline & $Q=N$ & $\xi_{i}$ & $\left|\Sigma \xi_{i}\right|$ & \multicolumn{4}{|c|}{$\bar{K}$} \\
\hline (1) & $\left(\begin{array}{ll}1, & 0 \\
0, & 1\end{array}\right)$ & $\begin{array}{l}-7.090888 \pm 7.301153 j \\
-7.090889 \pm 6.801143 j\end{array}$ & 28. 363554 & $\begin{array}{r}87.20369 \\
-9.177816\end{array}$ & $\frac{-3.059273}{86.77225}$ & $\begin{array}{r}13.19814 \\
-0.464163\end{array}$ & $\frac{-0.464164}{13.16541}$ \\
\hline (2) & $\left(\begin{array}{cc}10, & 0 \\
0, & \frac{1}{10}\end{array}\right)$ & $\begin{array}{l}-7.088719 \pm 7.078355 j \\
-7.088719 \pm 7.028354 j\end{array}$ & 28. 354876 & $\begin{array}{r}86.82618 \\
-9.185873\end{array}$ & $\frac{-0.030620}{86.82186}$ & $\begin{array}{r}13.17760 \\
-\quad 0.464724\end{array}$ & $\frac{-0.004647}{13.17728}$ \\
\hline (3) & $\left(\begin{array}{rr}100, & 0 \\
0, & \frac{1}{100}\end{array}\right)$ & $\begin{array}{l}-7.088698 \pm 7.055877 j \\
-7.088698 \pm 7.050877 j\end{array}$ & 28. 354792 & $\begin{array}{r}86.82240 \\
-\quad 9.185954\end{array}$ & $\frac{-0.000306}{86.82236}$ & $\begin{array}{r}13.17740 \\
-\quad 0.464729\end{array}$ & $=\frac{0.000046}{13.17739}$ \\
\hline
\end{tabular}

$$
\begin{aligned}
& \bar{H}_{c}(s)=\operatorname{diag}\left(h_{1}(s), h_{2}(s)\right) \\
& h_{i}(s)=\frac{1}{s^{2}+\gamma_{i 2} s+\gamma_{i 1}}=\frac{1}{\left(s-\xi_{i 1}\right)\left(s-\xi_{i 2}\right)}
\end{aligned}
$$

のように非干渉化をしてみる，比較を容易にするため

に，極 $\xi_{i j}$ を前述の(3)と同じように

$$
\left\{\begin{array}{l}
\xi_{11}, \xi_{12}=-7.088698 \pm 7.055877 j \\
\xi_{21}, \xi_{22}=-7.088698 \pm 7.050877 j
\end{array}\right.
$$

のように設計すると

$$
\begin{aligned}
& G=I_{2} \\
& \bar{K}=\left(\begin{array}{rccc}
86.85760 & 0 & 13.17740 & 0 \\
-12.17740 & 86.78711 & -1 & 14.17740
\end{array}\right)
\end{aligned}
$$

となる. $\bar{A}_{c} \equiv \bar{A}-\bar{B} \bar{K}$ を作って調べれば容易にわかる
ように， $\bar{S}_{c}$ を完全に非干渉化するためには， $k_{12}=k_{14}$ $=0, h_{23}=-1$ とするととが必要十分条件となる.

先程計算した(3)の $\bar{K}$ は $(A .10)$ の值にきわめてよ く似ているてと，またTable 1 で，(1) 一(3)になるに従 い, Table 1 の $\bar{K}$ の值は $(A .10)$ の值に漸近し, 特に $k_{12}, k_{14} \rightarrow 0$ となり, $k_{23}$ が -1 にかなり近いととがわ 功 よって, $S_{c}^{*}$ は $\varepsilon \rightarrow 0$ によって, 近似的に非干 渉化されるととが確認される．また， $S_{c} *$ が近似的に 非干渉化されるととは例題によってす確認できる.

また, $a=c=1, b=1,1 / 10,1 / 100$ なる制御対象に 対し， $Q=N=I_{2}, \rho=10^{-4}$ として設計すれば, Table 1 の $\bar{K}$ と完全に等しくなるととあ容易に確かめられ る. 